\title{
Street Names in Beirut, Lebanon
}

\section{KEVIN M. McCARTHY}

B

EIRUT, LEBANON, on the eastern shore of the Mediterranean Sea, is a city that has seen a great number of conquering armies and ideologies compete for dominance in its area. With a population of about 700,000, it is the capital of the Lebanese Republic, a major port in the Arab world, and a great international, commercial center. ${ }^{1}$ It is the major city of Lebanon, with about one-third of the country's total population living within the city's limits. ${ }^{2}$ Since the Suez crisis of 1956 Beirut has become even more important as airlines, banks, oil companies, and commercial enterprises from the rest of the Arab world have relocated there. ${ }^{3}$ Situated in a country that is about evenly divided between Christians and Moslems, the city has long been a cultural, commercial, and religious link between Europe and the Middle East. This former struggle between East and West, ${ }^{4}$ between Islam and Christianity, can be seen in the names of Beirut's streets and quarters. ${ }^{5}$

There are different theories about the origin of the name of the city. One historian of ancient times, Sanchoniathon, wrote that Beirut was built by the god Il or Illion in honor of his wife, who was named Beirut. ${ }^{6}$ Others have derived the name from Berothai ("And from Betah and from Berothai, cities of Hadadezer, King David took very much bronze"-2 Samuel 8:8) or from Berothah ("This shall be the boundary of the land: On the north side, from the Great Sea by way of Hethlon to the entrance of Hamath and on to Zedod, Berothah, Sibraim . . ."'-Ezekiel 47:15-16), but the other names in the text would seem to rule out Beirut. It is also possible that the name came from an Aramaic word Brouta "evergreen tree" because of the many trees around the city in former times. Other scholars derive the name from the Hebrew and

\footnotetext{
1 John B. Wolf, "Shadow on Lebanon," Current History, 58 (1970), p. 21.

${ }^{2}$ Harvey H. Smith et al., Area Handbook for Lebanon (Washington, D.C., 1969), p. 5.

${ }^{3}$ Wolf, pp. 21-26; for a study of the role of business in Lebanon see Yusif A. Sayigh, Entrepreneurs of Lebanon (Cambridge, Mass., 1962).

${ }^{4}$ See, for example, Carleton S. Coon, "The Impact of the West on Middle Eastern Social Institutions," Proceedings of the Academy of Political Science, 24 (1952), 443-66.

${ }^{5}$ For a study of another Middle Eastern city see Jack A. Dabbs, "Street Names in Baghdad, Iraq," Names, 10:3 and 4 (September and December, 1962), 172-80, 243-59. For a comparison of Beirut with Damascus and Aleppo see Christoph Stadel, Beirut, Damaskus, Aleppo-Ein stadtgeographischer Vergleich im vorderen Orient (Cologne, 1964); the author treats of such topics as geographical position, climate, history, and population.

${ }^{6}$ Harvey Porter, The History of Beirut (Beirut, 1912), p. 1.
} 
Phoenician word for "wells" bearoth because there were many wells and streams in the city. ${ }^{7}$

The city is first mentioned in the Tell-el-Amarna Tablets, which were discovered in Egypt in 1886. In these tablets, which date from the fourteenth century B.C., are letters from the governors of various cities and sections of the Middle East to the Egyptian king, who had appointed them to their posts. Beirut, which is mentioned as Beruta and which is sometimes signified by the cuneiform sign for "wells,"8 was at that time a small Phoenician port that was not as developed as Byblos to the north. ${ }^{9}$

From the earliest times the citizens of Beirut were engaged in trade and commerce, adopting Poseidon, the god of the sea, as their protective deity.$^{10}$ From time to time this area was the scene of battles as the armies of Middle Eastern rulers passed through, for example the armies of Ramses II in the thirteenth century B.C. and King Asarhaddon of Assyria in the seventh century B.C. ${ }^{11}$ Alongside a river outside Beirut there is inscribed into the rocks a memorial to several other conquerors, including Nebuchadnezzar II, the Roman emperor Marcus Aurelius Caracalla, the sultan Seif-ed-Din Barquq, and the French commander General Henri Gouraud. ${ }^{12}$

Alexander the Great conquered the city in 333 B.C. ${ }^{13}$ and after his death ten years later the Ptolemies of Egypt ruled. The Seleucids conquered the area (198-82 B.C.) and for a time the city was called Laodicea in Phoenice. ${ }^{14}$ Around 17 B.C. several Roman legions were settled in the city, thus making it one of the first Roman colonies in that part of the world. ${ }^{15}$ In 14 B.C. the city assumed the name Colonia Julia Augusta Felix Berytus in honor of Augustus' daughter. ${ }^{16}$ The Romans beautified the city with many forums, sanctuaries, statues, porticoes, and a theater, amphitheater, and baths. ${ }^{17} \mathrm{~A}$ very famous law school was established there that rivalled that of Athens and Alexandria. ${ }^{18}$ While the Romans

${ }^{7}$ E.S. Bouchier, Syria as a Roman Province (Oxford, 1916), p. 112.

- René Mouterde, Regards sur Beyrouth phénicienne, hellénistique et romaine (Beyrout, 1966), p. 9

9 Donald Harden, The Phoenicians (New York, 1962), p. 25.

${ }^{10}$ Philip K. Hitti, History of Syria (London, 1957), p. 310.

11 The Encyclopaedia of Islam, New Edition (London, 1960), I, 1137.

${ }^{12}$ Hachette World Guides: The Middle East (Paris, 1966), pp. 163-64.

${ }^{13}$ Helen and Frank Schreider, "In the Footsteps of Alexander the Great," National Geographic, 133 (Jan. 1968), 24-25.

14 A.H.M. Jones, The Cities of, the Eastern Roman Provinces (Oxford, 1971), p. 250; see also P. Roussel, "Laodicée de Phénicie," Bulletin de Correspondance Hellénique (1911), 433-40.

${ }^{15}$ Philip K. Hitti, Lebanon in History (London, 1957), p. 224; see also René Mouterde and Jean Lauffray, Beyrouth Ville Romaine (Beirut, 1952).

${ }^{16}$ Pliny, Natural History, Bk. V, chap. 17, \#20.

17 Henri Moukheiber, Beyrouth, mere des lois (Beirut, 1967), p. 18.

${ }^{18}$ Paul Collinet, Histoire de l'École de Droit de Beyrouth (Paris, 1925), pp. 16-25. 


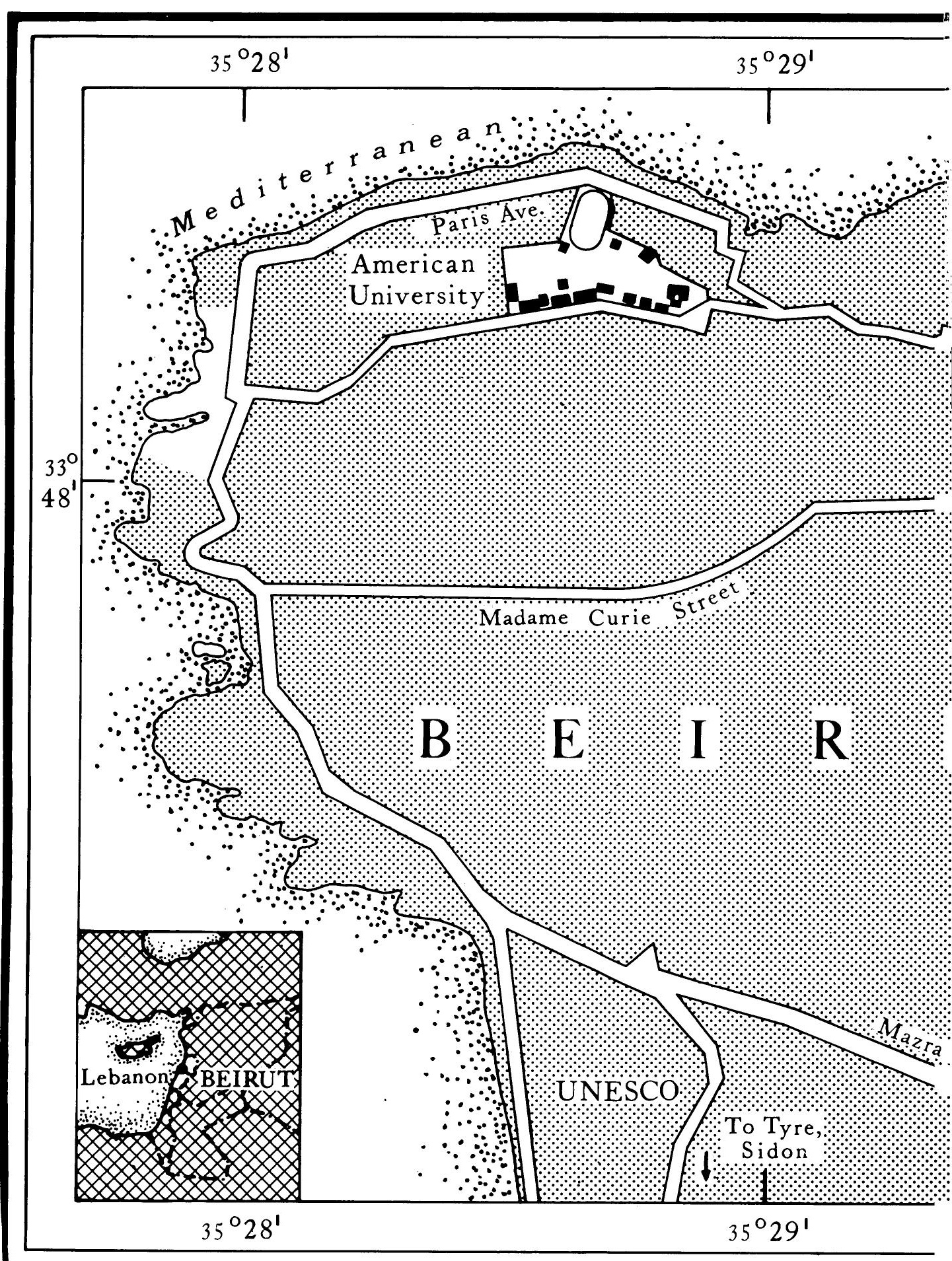


ruled from 14 B.C. to A.D. 633, Beirut became an important commercial and administrative center; Agrippa I, for example, built many large buildings there and held gladiatorial contests in the city. ${ }^{19}$

In A.D. 551 a great earthquake, tidal wave, and fire destroyed much of the city, killing about 30,000 people. ${ }^{20}$ The law school was abandoned, and the city went into a decline for the next few centuries. In A.D. 635 the Arabs conquered the city, made it Moslem, and repopulated it with colonists from Persia and the Arab countries. After Baldwin I captured it in 1110, the Crusaders controlled it during much of the twelfth and thirteenth centuries. The Mamelukes then governed this area until the start of the sixteenth century, ${ }^{21}$ when they gave way to the Ottoman Turks, who controlled the area up until 1914. ${ }^{22}$

By the middle of the eighteenth century Beirut was still only a small town of about 6,000 people. ${ }^{23}$ Its streets were narrow and dirty. The population increased to nearly 15,000 by $1840,{ }^{24}$ and after the French had built a road between Beirut and Damascus in 1863, completed the railway to Damascus and Aleppo, and built a port at Beirut, the city grew until it reached 100,000 at the end of the century. ${ }^{25}$ In the 1860's there was so much fighting between the Christians and Druzes of Lebanon that many people from the insecure mountainous regions moved to Beirut. ${ }^{26}$ The Emir Fakhr-ed-Din built many beautiful buildings in Beirut in the sixteenth century with the help of European architects, and it was from his time (1595-1634) that a Venetian and Cypriot colony settled in Beirut. ${ }^{27}$ When the Turks conquered the city, they destroyed many of the works that had been built up until that time. The Turkish-ruled city of Beirut was also bombarded by the Russians in 1770 , the British in 1841, and the Italians in $1912 .{ }^{28}$ Despite these repeated onslaughts the city managed to keep a great deal of its beauty so that Mark Twain in 1867 could write about "the beautiful city of Beirout, with its bright, new houses nestled among a wilderness of green shrubbery spread abroad over an upland that sloped gently down to the sea." 29

${ }^{19}$ Josephus, Antiquities, Bk. 19, chap. 7, \#5.

${ }^{20}$ Robin Fedden, Syria and Lebanon (London, 1965), p. 13.

${ }^{21}$ For a brief account of how Beirut languished under the Mamelukes see Ira M. Lapidus, Muslim Cities in the Later Middle Ages (Cambridge, Mass., 1967), pp. 16, $25,35$.

${ }^{22}$ Nicola A. Ziadeh, Syria and Lebanon (New York, 1957), p. 31.

${ }^{23}$ Hitti, History of Syria, p. 689.

${ }^{24}$ William R. Polk, The Opening of South Lebanon, 1788-1840 (Cambridge, Mass., 1963), p. 163.

${ }^{25}$ Hitti, Lebanon in History, p. 472.

${ }^{26}$ Antūn Dăhir Al-Aqīqi, Lebanon in the Last Years of Feudalism, 1840-1868, trans. Malcolm H. Kerr (Beirut, 1959), p. 59; for a recent study comparing similarities and differences among Lebanese villagers see George C. Fetter, "A Comparative Study of Attitudes of Christian and of Moslem Lebanese Villagers,” Journal for the Scientific Study of Religion, 4 (Oct. 1964), 48-59.

${ }^{27}$ Helmut Ruppert, Beirut: Eine westlich geprägte Stadt des Orients (Erlangen, 1969), p. 11. 
By the beginning of World War I there were more than 150,000 people in Beirut, ${ }^{30}$ but the streets were still not paved, and there were very few automobiles. After the War the French controlled Lebanon as a mandatary power and made Beirut the administrative center of the French Mandate of Syria and Lebanon. The first Lebanese Constitution was promulgated in 1926, but the French High Commissioner was still the ruler of Lebanon. The country was finally declared independent in 1941, and the French troops withdrew in $1946 .{ }^{31}$

Beirut is bordered on the west and north by the sea and on the east by the mountains. This geography and the commercial development of her port have had a great influence on her layout. Near the port there is a commercial area where there are mostly commercial buildings; ${ }^{32}$ the older part of town, near the port and Bab Edriss, has several open-air marketplaces that specialize in fruits and vegetables, secondhand furniture, and less expensive clothes. Martyrs Square, however, which is near the port and Bab Edriss, is usually the most congested part of the city since it is the loading and unloading place for a number of bus companies, the starting point for the city buses, the focal point of many businesses, and is near to the very old marketplaces; the cacophony from the hundreds of cars inching around the square, the frantic rushing to the waiting buses, and the continual horn blowing of the "Service" taxis make it a nightmare to the pedestrian. Riad Solh Street, which is nearby, contains the main Post Office, many banks, airline offices, and the headquarters of large companies; these buildings give the street a certain calmness and stateliness compared with the chaotic Martyrs Square.

The newer section of town, on and near Hamra Street, has modern stores with the latest fashions from Paris, expensive imports from around the world, and outdoor cafes. The theaters here are very modern and comfortable; one of them is even completely underground because of the lack of space in this very desirable commercial part of the city. The prestige and value of Hamra Street developed to a great extent from the nearby American University on Bliss Street. When Daniel Bliss purchased this land overlooking the Mediterranean in 1870, "it was a barren piece of land with only a mule track connecting it with the city"; ${ }^{33}$

\footnotetext{
${ }^{28}$ Philip Ward, Touring Lebanon (London, 1971), p. 25.

${ }^{29}$ The Innocents Abroad (Hartford, Conn., 1901), II, 173.

${ }^{30}$ Charles Issawi, ed., The Economic History of the Middle East, 1800-1914 (Chicago, 1966), p. 210.

${ }^{31}$ For a detailed explanation of Lebanon's administrative development and the various functions of each part of the government see George Grassmuck and Kamal Salibi, A Manual of Lebanese Administration (Beirut, 1955).

${ }^{32}$ For a comprehensive description of the free port see Raoul Colonna de Lega, La zone franche du port de Beyrouth (Beirut, 1957).

${ }^{33}$ Bayard Dodge, "The American University of Beirut," Journal of World History, 10 (1967), p.
} 
it was in fact "a place for refuse and a haunt of jackals" that Bliss bought for seven cents a square yard. ${ }^{34}$ The Avenue of Paris is a wide, tree-lined road between the green campus of the American University and the blue Mediterranean; with its breathtaking view of the sea it leads east to the finest hotels in the city, the Phoenicia and the St. George, and west near the famous Pigeon Rock to Embassy Row and the road south to Sidon.

Concentric to the commercial area around the port are schools, residences, apartment houses, and shops. Beyond this area are residential areas. The layout of the streets in the city is similar to that of other Arab cities in that many of the streets are narrow, twisting, and with deadends. ${ }^{35}$ The narrowness of these streets resulted from the desire to protect pedestrians from the sun or rain; the narrow, twisting streets were often covered or at least sheltered by the surrounding houses. ${ }^{36}$ It was only in 1952 that a Master Plan for Beirut was set up that established a system of major streets leading from the crowded commercial center to the outlying districts. ${ }^{37}$ Such four-lane roads have helped relieve the traffic congestion on the narrow, old streets of the downtown area. Even so, the continuing influx of people into Beirut has caused great overcrowding; the population of the city has grown from about 150,000 by the beginning of World War I to 232,000 in 1942 to over 500,000 in $1960 . .^{38}$

With the help of texts of ancient writers, the results of archeological digging, and the excavation for the construction of new buildings, archeologists have been able to reconstruct part of the ancient city. ${ }^{39}$ Ancient Roman coins have also been useful in showing sketches of a number of Roman buildings, for example the temple of Poseidon. The main north-south street, the Roman Cardo maximus, is the present-day Allenby Street; the main east-west street, the Roman Decumanus, is Maxime Weygand Street. The square where they crossed was the Forum, the site of the Great Mosque today. Around the Roman Forum rectangular areas, called insulae, were set out for the building of houses;

784. For another history of the early school see A.L. Tibawi, "The Genesis and Early History of the Syrian Protestant College," The Middle East Journal, 21 (1967), 1-15, 199-212.

${ }^{34}$ Stephen B. Penrose, Jr., That They May Have Life: The Story of the American University of Beirut 1866-1941 (New York, 1941), pp. 27 and 74.

${ }^{35}$ For a description of the daily activities on a typical Beirut street see Phyllis M. Sutton, Thank You, Arabs (Beirut, 1972), pp. 22-29. See also Charles W. Churchill, The City of Beirut: A SocioEconomic Survey (Lebanon, 1954) and A.H. Hourani, "The Islamic City in the Light of Recent Research," in The Islamic City, ed. Hourani and S.M. Stern (Oxford, 1970), pp. 9-24.

${ }^{36}$ For a detailed description of the kinds of houses, buildings, and streets in the city see Ruppert, Beirut, pp. 20-23, 53-125.

${ }^{37}$ Harvey Smith, Area Handbook, pp. 87-88.

${ }^{38}$ George B. Cressey, Crossroads: Land and Life in Southwest Asia (Chicago, 1960), p. 454.

${ }^{39}$ For a general outline of the old city see Robert du Mesnil du Buisson, Les anciennes défenses 
each area was about $360^{\prime}$ by $135^{\prime}$ and was bordered by smaller streets. ${ }^{40}$ From the time of the Romans the city has steadily expanded from around the port area, which is still the busiest and most congested part of the city, to the mountains on the east and up and down the coast.

In a study published in 1920, mention is made of the attitude of the Turks to street-naming: "Turkey has been, in all its projects, careless and indifferent as to most of its cities. It let the commoners name their neighborhoods and streets as they wished." ${ }^{41}$ It goes on to point out that once the Turks had left, the new administration of Beirut set up a street-naming committee that began putting up rectangular street signs written in French and Arabic. One of the first problems that the committee met was the question of how to satisfy the different religious sects and the different nationalities of the people living in Beirut. Lebanon's whole governmental life is based on a delicate balance between the Christians and Moslems; the Parliament, for example, is made up of a specified number of representatives from each of the Christian sects (Maronites, Greek Orthodox, Protestant, etc.), the Moslems (Sunnites, Shiites, etc.), and the Druze. ${ }^{42}$ If the government were to grant a favor to one of these sects, it would have to grant a corresponding favor to the other sects. Thus, in the naming of streets, the different religions had to be honored. An example of this is seen in the naming of a street after Omar Ben Abdul Aziz, one of the Ommayyad Caliphs. During the French Mandate, in the 1920's, the French authorities wanted to emphasize the French presence near the American University. To do this, they renamed a street near the University Jeanne d'Arc Street. The other nationalities felt slighted and so the French administration renamed a parallel street Omar Ben Abdul Aziz Street. ${ }^{43}$

In order to satisfy the Christians, streets in Beirut were named after Christian saints or after a Christian church already established on the street; such saints include Nicolas, Louis, Vartan, Charbel, Antonios, Maron, Michael, Elias, Mitr (or Dimitrius), John (or Yuhanna), and George. St. Maron was the Lebanese founder of the Maronite sect of Christianity; Charbel was a Lebanese holy man of the Maronites beatified within the last ten years. Some of these streets are designated by the name in English or French (Saint) while others have the Arabic

de Beyrouth (Paris, 1921), p. 249.

${ }^{40}$ Moukheiber, Beyrouth, p. 22.

${ }^{41}$ Lou is Sheikhou, "The New Names of the Streets in Beirut" (in Arabic), Al-Machriq, 18 (1920), p. 1025. For a more general treatment of the Turkish rule of Syria and Lebanon see "Gouvernement des Turks en Syrie" in Voyage en Égypte et en Syrie (Paris, 1959), pp. 361-67; also Gertrude L. Bell, The Desert and the Sown (London, 1907), p. 163.

${ }^{42}$ For an example of how delicate this balance is and how easily events can trigger violent political reactions see Fahim I. Qubain, Crisis in Lebanon (Washington, D.C., 1961).

${ }^{43}$ Beirut Directory (Beirut, 1971), p. 134. This work contains a brief historical and descriptive sketch of some of the main streets in Beirut. 
word for "lord" (Mar) preceding the name. Saints Peter and Paul are honored with their Arabic names, Boutros and Boulos; Petro Pauli Street was named, not after the two apostles, but after a Lebanese martyred by the Turks in 1916. The Good Shepherd is honored by Bon Pasteur Street. St. George, after whom Beirut's Bay of St. George may be named, supposedly slew the dragon in the vicinity of the city. ${ }^{44}$ For the most part these streets are in the Christian section of the city, especially the Achrafiyeh district where there are many Armenians and Greek Orthodox; there is no set pattern for these streets since some of them go north-south and others go east-west. The Moslems also had a number of their leaders honored in street names: Abou Bakr el-Siddic (the first Caliph after Mohammed), Omar ibn el-Khattaah (the second Caliph), and Omar Ben Abdul Aziz. The Druze had a great leader memorialized in Fakhr-ed-Din Street. ${ }^{45}$

One of the problems in dealing with Beirut's street names has been with the transliteration of Arabic sounds into Western languages, especially since several Arabic sounds were often written in two or three different ways in French. The voiceless pharyngeal stop of Arabic [q] was spelled -ck- in Bickaa, k- in Kader and Irak, and both -q- and -g- in Taqtaga. The Arabic voiceless velar fricative $[\mathrm{kh}]$ is spelled as $-\mathrm{k}$ in Cheik and kh- in Khalil. The voiceless interdental fricative [ $\theta]$ is -th-in Ibn al Athir and s- in Saalibi instead of Thaalibi; this last example could have been due to the influence of Turkish, which does not have interdental fricatives.

This same problem with transliteration is present on today's maps of Beirut. ${ }^{46}$ Though it is usually a question of just one or two letters, the result will often be confusion to the map reader. Examples of the same street in different spellings, depending on the map one uses, include Chaffaka and Chafaca, Salim Boustany and Selim Boustani, Said Akl and Said Acle, Borj Abou Haidar and Borje Abi Haidar. This inconsistency is due to the fact that different printing presses have different systems of transliteration. There are also morphological variations on the maps: Arabic ben and ibn, for example, both mean "son" or "son of." Thus one map has a certain street as Rue Ben Rochde, while on another map it is Ibn Ruchd or Ibn Ruchdi. The same is true of Rue Ibn Sina versus Rue Ben Sina. The difference between the forms ben and $i b n$ was clear in the past: between words $i b n$ was pronounced /ben/. An even

${ }^{44}$ Viola H. Winder, The Land and People of Lebanon (Philadelphia, 1965), p. 45.

${ }^{45}$ For a description of the various quarters of the city in which a predominant religious sect lives see Rupert, Beirut, pp. 25-53.

${ }^{46}$ The map accompanying the present study is based on the map in the Comprehensive Plan Studies for the City of Beirut, Beirut, 1968. Other maps consulted include the New Map of Beirut (Including the New Street Names Recently Adopted by the Lebanese Authorities), Middle East Airlines, n.d.; Map of Beirut, Pan Am. n.d.; Touristic Map of Beirut, prepared by Boulos F. 
more confusing practice on maps is caused by the failure of the printer to indicate by commas which is the first name and which the last. Thus $R u e$ $A b d$ El Wahab Inglizi is Rue Inklisi Abdul-Wahab on another map and Abdel Wahab Inglizi on a third. Rue Ahmed Tabbara is Tabbara Ahmad on a second map.

The street names on maps are often ignored though by people long accustomed to using other names for the streets. Since the Middle Ages when merchants in the same trade began to cluster together on the same street for protection from thieves and also to make sure that their competitors' prices stayed the same as theirs, a number of streets have been informally named after these merchants. ${ }^{47}$ Allenby Street has been called "The Street of the Tanners" since it contained mostly tanneries. ${ }^{48}$ Riad Solh Street has been known as "The Street of Upholsterers." Many of the carpenters of Beirut are still centralized in one place, Souk AnNajjarin "Carpenters Market." Fakhry Bey Street is the official name for what many Beirutis call "The Street of the Cloth Merchants," and Omar Ben Abdul Aziz Street is often called "Doctors Street" because there are more than one hundred doctors with offices on the street near the American University hospital. These streets have official names, but many Beirutis still refer to them by these unofficial names.

For the last year or so the Ministry of Social Affairs has been changing the names of some of the streets of Beirut to honor recent personages. While it was often customary to name a street after a popular deceased Lebanese ${ }^{49}$ this honor is now sometimes given to living persons. Thus, for example, Mazraa Boulevard has been renamed Salam Boulevard in honor of a recent prime minister in Lebanon, Saab Salam. This practice has been criticized by many Lebanese as being confusing and ill-timed. The Democratic Party has objected to the practice of naming streets after living people; it pointed out that it is normally done after a prominent person dies, in order to honor his memory. Such an honor-of having a Beirut street named after one-was not even accorded to Napoleon, Lenin, Churchill, or De Gaulle, while they lived.

This practice of changing street names is done in other countries, but perhaps with not as much frequency as in Beirut. It is possible that such name-changing may be both a part of the city's tendency to destroy the remnants of previous conquerors and to establish an identity of its own. ${ }^{50}$ And some of it is understandable. It was, for example, the practice during the French Mandate from 1921 to 1943 to rename many streets, squares, and sections after famous French political and military figures

Boulos, Beirut, 1970; Plan Général de la Ville de Beyrouth, Beirut, 1955.

${ }^{47}$ Ralph Patai, "The Middle East as a Culture Area," The Middle East Journal, 6 (1952), p. 14.

48 Beirut Directory, p. 36.

49 Desmond Stewart, Turmoil in Beirut (London, 1958), p. 106.

so Fedden, Syria and Lebanon, p. 11. 
and French place-names. Many of these have been changed again to honor Lebanese personages. ${ }^{51}$ Artois Street, for example, named after a former province of France, has been changed to Alfred Naccache Street to honor the President of Lebanon in World War II. Lyon Street, in honor of a French city that had a silk mill that bought Lebanese silk, has been changed to Emile Edde Street after a Lebanese who established a provincial government in 1943. Nancy Street, also after a French city, has become Dimachquieh Street, after an important Lebanese family. Perthuis Avenue, named after a Frenchman who founded the Diligence Company that operated between Syria and Lebanon, has been renamed John Kennedy Street. Georges Picot Street, named after a former French prime minister, has been changed to Omar Daouk Street after a former Lebanese prime minister. Bordeaux Street has become Dumant or Donan Street, probably after Jean Dunant, the founder of the International Red Cross.

The changes in names of many of the streets can be very confusing, especially to taxi drivers, who have a hard time keeping up with them. It is less disturbing to merchants and the post office since the usual mailing address of places in Beirut includes, besides the street name, the name of the building (which is usually the family name of the owners), and the section of Beirut, for example Al-Bizri Building, Sakiet-el-Jenzir (the street), Ras Beirut (the section), Beirut, Lebanon. Many companies complicate matters by using as their official address a nearby wellknown street, even though the companies are not on the street; for example, many businesses on Abdul Hamid Karame Street use the better-known Parliament Street on their letterheads, a practice that can lead to confusion for the unwary customer. Business cards or invitations to parties will often have a small map locating the shop or residence. And residents will often use well-known buildings, stores, or even statues in giving directions to their homes; thus an address might read: The Abu Khalil Building, Off Hamra Street, Close to the Nasrallah Bakery, Beirut.

Despite the name changes, many of which honor Lebanese, there are quite a large number of streets in Beirut named after foreigners, some of whom had nothing to do with Lebanon. These streets that are named after foreigners are found in several groups situated around the city. Around the American University, for example, there are streets named after California and America, as well as a number of Americans including John Kennedy, Roosevelt (although whether it is Theodore or Franklin is not clear), Henry Ford, Daniel Bliss ${ }^{52}$ (the founder of the

\footnotetext{
${ }^{51}$ Much of this was due to the weakening of French influences; see, for example, Henry $\mathrm{H}$. Cumming, Franco-British Rivalry in the Post-War Near East: The Decline of French Influence, London, 1938.

52 "The first street sign of Beirut, set up by the Provisional Government of 'Umār Da'ūq in 1918,
} 
American University), Bayard Dodge (the third president of the university), Dr. Harris Graham (an American doctor in Beirut in the nineteenth century), and Cornelius Van Dyck (one of the nineteenthcentury Protestant missionaries in Beirut). Nearby and in the section where much of the foreign community lives are streets named after Ahram (Arabic for the "pyramids" of Egypt), Bahrein, Cairo, Granada, Kuwait, Nigeria, Paris, and Rome, as well as a number of foreign personages such as Adonis, Joan of Arc, Simon Bolivar, Georges Clemenceau (the French premier and World War I leader), Marie Curie (the discoverer of polonium and radium), Mahatma Gandhi, Edward Spears (the British minister in Beirut after World War II), and Venus.

Near the UNESCO buildings that housed the 1952 UNESCO meeting are streets honoring the United Nations and a number of countries and cities, for example Australia, Baghdad, Berlin, Ghana, Khartum (the capital of the Sudan), Port Said (a city in northern Egypt), Venezuela, and Vienna. Among personages honored in that section of the city are the American Thomas Edison, the Swedish Count Folke Bernadotte (the mediator in the Arab-Israeli conflict who was assassinated by a group of extremists in 1948), Cleopatra, Zenobia (the queen of Palmyra in the Syrian Desert in the third century A.D.), and a group of famous European artists that include Beethoven, Leonardo da Vinci, Mozart, Schubert, and Raphael.

Near the port and in the older section of the city are streets named after Argentina, Brazil, France, London, Madrid, Mexico, Phoenicia, the Sahara, Senegal, and Uruguay; there are also streets there named in honor of Agrippa (one of the early builders of Beirut), Viscount Edmund Allenby (the British general in command of the British Army in Palestine in World War I), Francois Chateaubriand (a French writer of the nineteenth century), Sir Alexander Fleming (the discoverer of penicillin), Marshal Foch (the supreme commander of Allied armies in France in World War I), General Henri Gouraud (the first French High Commissioner of Syria and Lebanon after World War I), Maxime Weygand (the successor to Gouraud as High Commissioner), Pasteur, Ibrahim Pasha (an Egyptian general who occupied Lebanon in the early nineteenth century), Justinian (the Byzantine emperor who rebuilt Beirut after the earthquake of 551), and Cadmus (the founder of Thebes and the supposed carrier of the Phoenician alphabet to Greece). In the Achrafiyeh section of eastern Beirut, where the Greeks and Armenians live, ${ }^{53}$ are streets named after Alexander the Great, the Armenian people

was in the name of 'Bliss." ' Zeine N. Zeine, The Struggle for A rab Independence (Beirut, 1960), p. 70 , fn. 3.

${ }_{53}$ The French had settled many Armenian refugees in and around Beirut in the early part of this century in order to establish and keep a Christian majority in Lebanon. See A.H. Hourani, Minorities in the Arab World (London, 1947), p. 69; chapter 9 of this book gives a good description 
in general, several Christian clergymen, St. Louis, and the Good Shepherd; in the same section are streets named after Athens, Ararat (the mountain in the Armenian part of eastern Turkey), Bethlehem, Guatemala, Libya, Moscow, and Paraguay.

The great number of streets in Beirut that are named after foreign cities and countries indicates to some degree the international bearing of the city. ${ }^{54}$ These streets often either intersect with one another or are found grouped together in small pockets around the city. There does not seem to be any attempt to make such streets run parallel to each other or to run in the same direction. This interest in foreign places has come from Beirut's long history of being one of the leading commercial and cultural centers of the Middle East. ${ }^{55}$ There has also been a large foreign community in Beirut, sometimes estimated at one-fourth of the city's population. ${ }^{56}$ The city is at one end of the major international highway in Southwest Asia, is the busiest shipping port in the eastern Mediterranean, handling over 3,000 ships a year, and has the major international airport in the Middle East. ${ }^{57}$

With its international bearing and great degree of Westernization the city has also become quite foreign to many of the more rural Lebanese and Syrians. ${ }^{58}$ Its streets are clogged with big American and German cars, its nightclubs feature the latest Parisian acts, its newsstands have dozens of American, French, and German magazines. ${ }^{59}$ There is also another factor involved here, namely that a number of South American and African nations have streets named after them in Beirut because of the many Lebanese who have gone to these countries in the past to set up businesses and commercial enterprises. ${ }^{60}$ There are, for example, almost a million Lebanese in Brazil, a country in which the Lebanese have prospered and acquired great wealth and power. ${ }^{61}$ Furthermore many of

of the religious minorities in Lebanon. See also Avedis K. Sanjian, The Armenian Communities in Syria under Ottoman Dominion (Cambridge, Mass., 1965), esp. pp. 59-66; and M. Berenstein, "The Levant States under French Mandate and Problems of Emigration and Immigration," International Labour Review, 33 (1936), 685-720.

54 For the influence of other countries on Lebanon see Noel Verney and George Dambmann, Les Puissances Étrangères dans le Levant en Syrie et en Palestine, Paris, 1900.

ss For a detailed analysis of Lebanon's dependence on foreign trade see Nadim G. Khalaf, Economic Implications of the Size of Nations, With Special Reference to Lebanon (Leiden, 1971), esp. chap. 8.

s6 J.W. Crowfoot, "Syria and the Lebanon: The Prospect," The Geographical Journal, 99 (1942), p. 133.

${ }^{57}$ Cressey, Crossroads, p. 231.

so Ralph Patai, Golden River to Golden Road: Society, Culture and Change in the Middle East (Philadelphia, 1962), p. 274.

s9 Raymond Loir, "Life in the Lebanon," The Contemporary Review (May, 1955), pp. 336-38.

${ }^{60}$ For the effects of emigration on the country see Fuad I. Khuri, "The Changing Class Structure in Lebanon," The Middle East Journal, 23 (1969), 29-44.

${ }_{61}$ "Brazil: Sons of the Phoenicians," Newsweek, 8 Jan. 1968, pp. 39-40. See also Tanus J. 
Beirut's streets that are named after foreign places commemorate countries in which there are cities or streets named after Lebanon. This is not true however of the one American state that has a Beirut street named after it, California (California Street); while California may represent the United States in the minds of many Lebanese, there are actually 18 American states that have a Lebanon, two states that have a Sidon (after Sidon, Lebanon), and one state that has a Phoenicia (the ancient name of Syria and Lebanon). ${ }^{62}$

Of the various places and squares in Beirut several should be mentioned here. Place des Martyrs or Martyrs Square was the site of the hanging of the men whom the Turks accused of plotting against the Ottoman Empire; these men have been looked on as martyrs to the cause of Lebanese independence. This Place is still called by three different names: The Borj, Place des Martyrs, and Place des Canons. It was first called The Borj or "The Tower" since a watchtower used to stand there to control the three gates leading into the city. It was called the Place des Canons during the French Mandate because there were two cannons in front of the nearby city hall at the time.

Debbas Square was named after Charles Debbas, the first Lebanese president of the Republic. He was elected in 1926 during the French Mandate and remained in office until 1932, at which time the French High Commissioner suspended Parliament and made Debbas President for two more years. The Place de l'Étoile was named after the Place de l'Étoile in Paris, which itself has recently been renamed in Charles de Gaulle's honor. ${ }^{63}$ The Lebanese Place de l'Étoile is the meeting place of six streets. In the middle of this square there was a clock tower for many years; it was the gift of a wealthy Lebanese emigrant, Michel al-Abed, who returned to Lebanon about 30 years ago after living for a long time in Mexico. There are some people who still call this square Place elAbed. Place Riad Solh was named in honor of one of the fathers of Lebanese independence; there is a statue of the man in the center of the square.

It has been the practice in Beirut's history to destroy much of what was built in the past either to make way for the new or to efface what was alien to the present inhabitants or leaders. It was also done by a number of the foreign conquerors; for example, the Turkish ruler in World War I, Jamal Pasha, destroyed much of the old city because he thought that pan-Arab patriots were hiding there. ${ }^{64}$ The naming and renaming of streets in Beirut have also shown this tendency to erase unpleasant

\footnotetext{
Bastani, O Libano e os Libaneses no Brasil, Rio de Janeiro, 1945. For a similar treatment concerning the Lebanese in Cuba see Teófilo H. Salomón, Cuba y Libano, Havana, 1957.

${ }_{62}$ "Eastern Names in the Western World," Aramco World, Aug., 1954, pp. 6-8.

${ }^{63}$ Time, 22 Nov., 1971, p. 21.

${ }^{64}$ Bruce Condé, See Lebanon (Beirut, 1960), p. 1.
} 
memories of the past and honor current favorites among the Lebanese. On the other hand because "the Arab is preoccupied with his past" 65 and often feels that the present can not compare with the former glories of the Arab conquests, he memorializes past Arab leaders in the names of his streets and often takes an active part in letting his feelings be known about the naming of streets, especially when he disagrees with the names decided upon by the government. For the most part, though, the Beirutis usually show an apathetic disregard for the naming and renaming of streets, usually just shrugging it off as a prerogative of the government and one that is probably politically or financially motivated. Throughout its long history Lebanon has followed a course of "selective adaptation and assimilation" ${ }^{66}$ and thus her street names, especially in the capital city of Beirut, are a good index to those leaders she considers important and honorable.

\section{University of Florida}

\footnotetext{
${ }^{65}$ Sania Hamady, Temperament and Character of the Arabs (New York, 1960), p. 217.

${ }^{66}$ Samir Khalaf, "Primordial Ties and Politics in Lebanon," Middle Eastern Studies, 4 (1968),
} 244.

\section{PLACE-NAME PROGRESS REPORT 1975}

All members of the Society who are engaged in place-name work are reminded of Professor Edward C. Ehrensperger's annual place-name progress report which has become a regular part of the annual meetings. News of research and new projects should be sent to Professor Ehrensperger at his home:

1002 Mulberry Street

Yankton

South Dakota 57078 